\section{Science and trans-science}

\author{
Alvin M. Weinberg
}

The Rise and Fall of Nuclearism: Fear and Faith as Determinants of the Arms Race. By Sheldon Ungar. Penn State Press: 1992. Pp. 214. \$32.50 (hbk), $\$ 14.95$ (pbk).

Containing the Atom: Nuclear Regulation in a Changing Environment, 1963-1971. By J. Samuel Walker. University of California Press: 1992. Pp. 533. \$50, £34.50.

ALTHOUGH both of these books are 'historical' accounts of nuclear development in the United States, they differ both in the segments of the development they cover and, more fundamentally, in their approach to, even their conception of, 'history'. Sheldon Ungar is a sociologist. He covers the nuclear arms race not so much as history but as a phenomenon to be interpreted in an arcane sociological idiom. J. Samuel Walker is the official historian of the US Nuclear Regulatory Commission (NRC). This second volume of the official history of the Nuclear Regulatory Commission* covers, in a strict, thoroughly documented fashion, the tortured events that led to the public's disaffection with nuclear energy and to the attempts by the Atomic Energy Commission to quell that disaffection.

Ungar's book poses serious difficulties for the reader, such as me, who is unfamiliar with the methods, and perhaps the pretensions, of modern sociology. He defines 'nuclearism', following Robert Lifton, as "the faith in awe-inspiring power" (of the atom) as a source of salvation - for example, the United States was able to guarantee the freedom of Western Europe by threatening a nuclear response to Soviet aggression.

\section{Nuclear fear}

But according to Ungar, this "numinous" aspect of the bomb was always accompanied by "nuclear fear": the bomb was both omnipotent and dreadinspiring. The various episodes in the nuclear arms race - missile gaps, arms limitation treaties, Atoms-for-Peace, the Cuban missile crisis, even the eventual ending of the Cold War - resulted, Ungar believes, from oscillations in the relative strengths of the polity's appreciation of one or the other aspect of the bomb. When confidence in the bomb's omnipotence dominated, US foreign policy, as in Vietnam, was aggressive. But when confronted with the reality of the bomb, as in the Cuban missile crisis, nuclear dread prevailed. The United *For a review of the first volume, see Nature 318 , 607 (1985)
States, as well as the Soviet Union, was cautious, and the crisis was resolved.

Ultimately, according to Ungar, 'nuclearism' failed: nuclear dread made the bomb "unusable". Here Ungar quotes McGeorge Bundy, who, in his book Danger and Survival: Choices About the Bomb in the First Fifty Years (Random House, 1985), points out the "enormous gulf between what political leaders really think about nuclear weapons and what is assumed in calculations of relative advantage in simulated strategic warfare. ... In the real world of real political leaders . . . even one hydrogen bomb on one city would be recognized . . . as a catastrophic blunder." Thus, as Tom Schelling first pointed out, and as Ungar implies, the fall of nuclearism suggests that the world may be creating a "tradition of non-use"; perhaps this tradition of non-use, if sufficiently strong, will forever prevent a nuclear holocaust.

Readers who wish to know just what happened during the heyday of nuclearism will find Bundy's Danger and Survival a far more lucid and better documented work than Ungar's book. For those who understand and are sympathetic to sociological interpretation of history, Ungar's book provides provocative, though unprovable, insights.

Containing the Atom is a marvellously informative account of how the US Atomic Energy Commission coped with its responsibility to regulate nuclear energy during Glenn Seaborg's chairmanship. Nuclear energy for electrical power production was just coming of age; but public apprehension over the safety of nuclear energy was also beginning to emerge at this time.

The commission was mandated by the 1954 Atomic Energy Act to produce nuclear weapons, to promote the private use of atomic energy and to ensure the safety of commercial nuclear power. To carry out the last mandate, the commission established a small regulatory staff. Even at the time, many observers realized that the commission's regulatory responsibility could be in conflict with its other two promotional responsibilities. Walker's tale of the often excruciating dilemma the commission faced in discharging its conflicting responsibilities reads like a novel - with heroes, villains, suspense and human frailties.

The difficulties first became apparent during the original fallout scare of the 1950 s. At the heart of the issue was the biological effect of low levels of radiation: did exposures of the order of background radiation cause harm, as Linus Pauling claimed, or were these levels innocuous, as the commission in- sisted? To a remarkable degree, the question of the effect of low levels of radiation was at the bottom of most of the controversies that embroiled the commission during the 1960s: waste disposal, reactor safety and, of course, radiation standards. Even in a reactor accident, the huge number of casualties predicted in the worst conceivable accident results from assuming a nothreshold linear hypothesis. But the question is trans-scientific: at levels around background, science cannot say what is safe, what is not.

\section{Acceptable standards}

How can the regulators set standards of acceptable exposure in such cases? Here I believe that the entire nuclear regulatory apparatus fell into a trap. Standards for the public were set as 1/10 (later $1 / 30$ ) of the 0.05 sieverts per year established for radiation workers. This standard came from the experience of early $\mathrm{X}$-ray workers and really had little bearing on chronic effects of radiation. Far better would have been to set radiation standards as a small fraction of the unavoidable background level $(0.001$ sieverts per year). Whatever harm, if any, is caused by exposure at this regulatory standard, it would be small compared with what everyone already accepts. The commission did eventually lower the permissible exposure to the public from a nuclear power plant to some $5 \times 10^{-5}$ sieverts per year - but only after an excruciating, even humiliating, confrontation with congressman Chet Holifield, chairman of the Joint Committee on Atomic Energy.

How could the commissioners, honourable and able people, discharge these conflicting responsibilities in a way that would satisfy both promoters and detractors of nuclear energy? Obviously they could not satisfy everyone, perhaps even themselves. This was poignantly illustrated by the commission's suppression, in 1965, of the famous revision to report WASH-740. In this report, Brookhaven scientists had estimated that the worst possible reactor accident could contaminate as much as 100,000 square miles of land and cause damage of $\$ 17$ billion. Although commissioner John Palfrey urged publication of these findings, the rest of the commission objected - basically because publication would erode public support for nuclear power. In the end, Palfrey acceded to the majority's view.

In retrospect, the commission's decision was probably wrong. But the pressures on the commission by the Joint Committee and the nuclear industry, as well as their own nobly inspired desire to see some good, not only evil, from nuclear fission, almost like a Greek tragedy led them to their decision. And 
so it went for. each of the issues that the commission had to confront: mining, emergency core-cooling, waste disposal, thermal pollution, environmental impact - in every case the commission tried to balance its desire not to impede nuclear power with its responsibility to assure public health and safety. Although it is easy in retrospect to criticize the commission for being overly permissive in its regulation of nuclear energy, the results as seen in 1993 are proof that something was being done right. Despite the accident at Three-Mile Island, no member of the US public has been harmed by nuclear power.
That an official history of a US government agency pulls no punches, but gives the facts just as they were, is remarkable. Walker and the Nuclear Regulatory Commission are to be congratulated for providing us with so balanced and accurate an account of how nuclear regulatory policy was established in the United States.

Alvin M. Weinberg, former director of Oak Ridge National Laboratory, is in the Medical Sciences Division, Oak Ridge Institute for Science and Education, PO Box 117, Oak Ridge, Tennessee 378310117, USA.

\section{Ancient aquatecture}

\section{J. T. Lewis}

Roman Aqueducts and Water Supply. By A. Trevor Hodge. Duckworth: 1992. Pp. 504. £55, $\$ 78$.

ROMAN aqueducts are a never-failing source of interest to archaeologists, engineers and laypeople alike. So it is astonishing that no general study has hitherto been published in English or (of anything like this quality) in any other language. Hodge triumphantly combines deep scholarship and lucid interpretation, while guiding nontechnical readers considerately and painlessly through the inevitable quagmire of hydraulic princi-

\section{IMAGE \\ UNAVAILABLE FOR COPYRIGHT REASONS}

ples. He follows the water over its whole course from intake to domestic plumbing, and finally sees it down the drain. En route he discusses the Romans' predecessors, wells and cisterns, surveying, irrigation, mills and baths, and urban distribution. The book is thorough, utterly practical and highly readable even at times funny - and it will be a long time before it is superseded.

Our knowledge about the subject is limited to two principal literature sources. Frontinus's justly famous book on the aqueducts of Rome is informative about administration but thin on technology, and does not necessarily apply to other cities. Vitruvius, although trying to describe the practicalities, does not always succeed, to the point where one wonders if he knew what he was talking about. The great bulk of the evidence, then, is archaeological. The most obvious components - the $\Phi$ arcades striding across the Campagna, the mighty bridges of Segovia and Tarragona or the Pont du Gard - are the least typical, for the aqueducts mostly ran underground in cutand-cover trenches or in tunnels. With all their accessories such as dams, inverted siphons, settling tanks and water towers, aqueducts provide plenty of scope for debate about how they worked.

So, inevitably, not all specialists will agree with Hodge's conclusions. He emphasizes the risk, for instance, of mains pressure blowing the plug of domestic taps out of their hous- ings, without considering the attempts to hold them down; and many would question his remarks that most Roman watermills were supplied by aqueduct, or that in northern Europe the horizontal waterwheel predominated.

His subject is so large that some prime examples have found no place: Dorchester's open-channel aqueduct; Mérida's fine system of sewers; Frontinus's information on the maintenance staff at Rome. Hodge shirks the fascinating issue of Lincoln, where the aqueduct's source lay 30 metres below the water tower. And Norman Smith's recent paper on the Pont du Gard, although in the bibliography, is not discussed. Smith suggests that the topmost tier of small arches, a unique feature, was a last-minute addition to retrieve a disastrous error in levelling. With these arches, the aqueduct just worked, falling only 6 metres in $25 \mathrm{~km}$ between Gard and Nîmes, the minimum gradient being an extraordinary $7 \mathrm{~cm}$ per $\mathrm{km}$; without the arches, the aqueduct would not flow. The idea is plausible, for Roman engineers, like any others, were not infallible.

Such omissions as these, however, are minimal when set against the whole. Many a hoary myth is laid to rest, most notably that the Romans avoided pressure systems because of the weakness of their pipes. On the contrary, Hodge clearly shows that when crossing a valley up to about 50 metres deep (as at the Pont du Gard), they used a bridge; if deeper, they used an inverted siphon. To cite the extreme instances, at Beaunant near Lyon the head was $123 \mathrm{~m}$ and the pressure $1,207 \mathrm{kPa}\left(175 \mathrm{lb}^{-2}\right)$, whereas on the Hellenistic siphon at Pergamon the figures were about $190 \mathrm{~m}$ and 1,825 $\mathrm{kPa}\left(265 \mathrm{lb}^{-2}\right)$. So much for fear of pressure: these siphons were not only built with lead pipes, but worked.

With such achievements, few would deny that Roman aqueducts were a magnificent feat of engineering and organization. This, and the benefits they brought, Hodge fully acknowledges. Neither is he starry-eyed about them, for he sees them in context. Often they were status symbols, crippling to the council's budget, built to keep up with the municipal Joneses, supplying vast quantities of water to cities whose drains could not cope. Most urban dwellings, moreover, were not on the mains for reasons of cost or lack of head, and continued to rely on wells and rainwater cisterns just as they always had. Which goes to show that in no age or society does engineering, however prestigious and expensive, necessarily impart universal benefit.

M. J. T. Lewis is in the Department of Adult Education, University of Hull, 49 Salmon Grove, Hull HU6 7SZ, UK. 